\title{
Forecasting for Healthcare Expenditure of Turkey Covering the Years of 2018-2050
}

\author{
2018-2050 Yıllarını Kapsayan Türkiye'nin Sağlık Harcamalarına İlişkin Tahminler
}

\author{
Abdulkadir ATALAN ${ }^{1}$
}

\begin{abstract}
The aim of this study was to measure health expenditure (HE) estimates for Turkey for the next 32 years. Considering HE data of Turkey for the period from 1975 to 2017 over 42 years, more than one equation was obtained for estimation. Equations were formed in trendline analysis in order to estimate the $\mathrm{HE}$ values in the long term by considering the reliability levels of the data. The data were used for HE of Turkey as a share of gross domestic product (GDP), which ranges from less than $1.49 \%$ to $5.53 \%$ in this research. Estimation of HE of Turkey for the next 32 years (the period from 2018 to 2050) according to the formulas developed were considered in this research. For the years to come, the maximum ratio of $\mathrm{HE}$ of $8.56 \%$ was gained by the exponential trend for the year 2050. In the opposite direction, the minimum HE ratio was expected to be $2.17 \%$ of the $5^{\text {th }}$ order equation for 2018 . $7.45 \%$ covers the years after 2030 due to the exponential distribution for the average the values of HE. While the average value obtained by the $6^{\text {th }}$ order equation, which has the highest reliability rate is 3.45 $\%$, the difference between the maximum and the minimum was calculated as $3.4479 \%$. For the period of 2018-2050, an average of HE rates of Turkey was 5.07 $\%$, whereas the maximum value was calculated to be $6.68 \%$. The minimum value of HE was estimated at $3.58 \%$ of GDP. As a result, Turkey needs to upgrade the amount of budget allocated for healthcare on the purpose of improving healthcare infrastructure.
\end{abstract}

Keywords: Healthcare Expenditure, Trendline Analysis, Estimations, Equations

\section{ÖZ}

$\mathrm{Bu}$ çalışmanın amacı gelecek 32 yıl için Türkiye sağlık harcamaları (SH) tahminlerini ölçmektir. Türkiye'nin 1975-2017 yılları arasında 42 yıl boyunca elde edilen SH verilerine dayanarak yapılan tahminler için birden fazla denklem elde edilmiş̧ir. Verilerin güvenirlilik düzeyleri göz önünde bulundurarak uzun vadede SH değerlerini tahmin etmek için trend eğilim analiz denklemleri oluşturulmuştur. Gayri safi yurtiçi hasılanın (GSYH'nin) \%1,49 ile \%5,53 arasında değişen Türkiye SH verileri kullanılarak gelecek 32 yıl (2018-2050 dönemi) için Türkiye'ye ait SH değerleri tahmin edilmiştir. Maksimum SH oranı 2050 y1lı için üstel eğilim gösteren denklem uygulanarak yaklaşık \%8,56 hesaplanmıştır. Aksi takdirde, minimum SH oranı 2018 yılı için beşinci dereceden denklem ile $\% 2,17$ olarak elde edilmiştir. Üstel dağılım metoduyla 2030 yılından sonraki yıllar için ortalama SH değeri $\% 7,45$ hesaplanmıştır. En yüksek güvenirlilik oranına sahip olan altıncı derecedeki denklem tarafından elde edilen ortalama değer \%3,48 iken, maksimum ve minimum SH değerleri arasındaki farkı \%3,45 olarak bulunmuştur. Çalışmanın sonuçlarına göre $\mathrm{SH}$ oranının, yapılan analizlere göre GSYH'den daha hızlı artmadığı gözlemlenmiştir. 2018 ile 2050 yılları arasında Türkiye'ye ait SH oranın ortalama olarak $\% 5,07$ bulunurken, maksimum değer \%6,68 olarak hesaplanmıştır. Minimum SH değerinin ise GSYH'nin \%3,58'i olarak tekabül edeceği görülmektedir. Sonuç olarak, Türkiye'nin sağlık alt yapısını geliştirmesi adına sağlık için ayrılan bütçenin yükseltilmesi gerekmektedir.

Anahtar Kelimeler: Sağlık Harcamaları, Trend Çizgi Analizi, Tahminler, Denklemler

${ }^{1}$ Dr. Öğr. Üyesi, Gaziantep İslam Bilim ve Teknoloji Üniversitesi, Mühendislik ve Doğa Bilimleri Fakültesi, Endüstri Mühendisliği Bölümü, abdulkadiratalan@gmail.com, ORCID: 0000-0003-0924-3685

\begin{tabular}{|c|c|c|c|}
\hline İletişim / Corresponding Author: & Abdulkadir ATALAN & Geliş Tarihi / Received: & 11.03 .2019 \\
\hline e-posta/e-mail: & abdulkadiratalan@gmail.com & Kabul Tarihi/Accepted: & 15.12 .2019 \\
\hline
\end{tabular}




\section{INTRODUCTION}

Typically, people expect fast and highquality services concept in a good healthcare system. ${ }^{1}$ Quality services depend on the level of economic dimensions from a public perspective in almost all industrial and health sectors. Over the past few years, health economics has attracted great interest from researchers. The underlying reason is that as an important indicator of the economic growth of a country, health expenditure (HE) of states are expressed in researches. ${ }^{2}$ In economically developed countries, there is a rapid trend in the increase of HE. ${ }^{3}$ The main thought can be attributed to the demographic structure of the society for this situation. Especially, population characteristics such as age, gender would have a great impact on HE.

The desire for a long life and qualified health services of people are rapidly increasing the changes and developments in the field of healthcare. ${ }^{4}$ In other words, the relationship between healthcare-related life quality measures and $\mathrm{HE}$ is obvious as examined in previous studies. ${ }^{5}$ This condition triggers both the household and countries to pay high amount for healthcare services which influences HE in turn. ${ }^{6}$ In scientific studies, some factors have been taken into consideration because of the increase or decrease in the HE over the years. The researchers have examined both fixed and dynamic effects to analyze the factors related to the increased total $\mathrm{HE}$ which is the combination of government and out-of-pocket expenses. $^{7}$ This distinction is usually made depending on the healthcare system types of countries. ${ }^{8}$ There are significant differences between the out-of-pocket and government expenditures in HE of social and non-social healthcare systems. Though, data on HE of Turkey for the future years will be obtained without considering any factors, regarding directly HE for the years 1975-2017 in this study.

In some studies, the status of healthcare to be fast and quality is attributed to the higher HE. ${ }^{9}$ However, how effective and efficient HE by countries is still a hot topic of discussion in terms of waste in the economy of healthcare in reports. The HE of developed countries is increasing in proportion to their economies. ${ }^{10}$ For instance, HE of US is quite high compared to other developed countries. The HE of US was around $7.20 \%$ in 1975 and rose to 17.10 $\%$ in 2017. ${ }^{11}$ Within the same time distribution, the $\mathrm{HE}$ of Turkey was determined $2.20 \%$ in 1975 and $4.20 \%$ in 2017. In such comparisons, HE per capita is very high, even if the countries' populations are taken into account in order to evaluate the amount of HE of countries. ${ }^{12}$ Another factor is the types of healthcare systems that countries have. ${ }^{13}$ Toht 2019 advocated that there is no pure healthcare system in the world, and all national healthcare systems are hybrid. The low level of state intervention in the US healthcare system (a large number of private health enterprises) causes the total $\mathrm{HE}$ of the United States to be higher, such as the UK, Spain, Italy, Canada, Turkey, etc. (universal health systems). ${ }^{14}$

From global perspective, however, the expenditure in terms of healthcare more effectively in order to balance future demands more efficiently by the countries. By making decisions in an anticipatory manner, while implicitly considering the current economic situations of healthcare systems for potential requests and the quality of services can be improved. In the last decades, many applications for the economics of the healthcare sector have been discussed. It is known that the reliable value of $\mathrm{HE}$ is obtained in the conditions of the existence of which methods call economy structures. Dissimilar methodologies exist for assessing and estimating the HE of countries. Typically, these contain the time series models for HE in case of forecasting accurate. Similar theories exist in other researches such as statistical analyses to derive the regression equations in order to forecast the future amount of HE.

Time series analysis can be carried out to determine the events likely to occur. ${ }^{15,16}$ For example, there may be a time-dependent movement of the data depending on the increase in the economy by the measures taken with the time series model and the 
forecasting of the next year can be estimated depending on the period of this increase and decrease. ${ }^{17}$ Another example is the moving average method used in economic analysis and in many areas. ${ }^{18}$ Estimates can be made on how the exchange will change with the moving average chart. These estimates are particularly important in financial systems in the field of healthcare.

An analysis method is used to compare the actual performance and predicted values using the trend line of economic performances. ${ }^{19,20}$ The basic element in this method is to follow the trend by using historical data. ${ }^{21}$ This enables a comparison between the estimated data and actual data. A trendline concept, a powerful tool for forecasting expenditure typically arising in the field of healthcare economy to predict HE for Turkey and analyze data depend on confidence values of equations, was applied. Time-dependent data will be clarified in order to obtain accurate results of reality. This analysis needs the use of a very sophisticated forecasting method, which admits the formation of the economy of countries prediction under different situations such as economic crisis. ${ }^{22}$ Therefore, the ratio of HE in Turkey as in other countries shows varied over time. Data of HE was used for the period from 1975 to 2017 over 42 years in Turkey and was tried to estimate HE of Turkey for the next 33 years to study this. The purpose of creating equations depend on confidence level are to estimate HE in the long term. The data covered include the total HE spent by both households and governments in this research.

That the occasional surge of Turkey's HE amounts depends on a lot of reasons. However, the factors affecting HE were not considered in this study. In this study, we just wish to contribute to the literature as a field of research into health spending as an important warning to Turkey. Therefore, we dealt the HE of Turkey not to make a proper comparison with other countries or international organizations such as OECD, G20, G7, etc. The comparison of only the results was briefly summarized in the methodology and conclusion part of the study.

Section 2 contains detailed information on the methodology. Mathematical formulations showing the distribution of data for HE were given in this section. Section 3 contains the results and reviews with a discussion of the directions of the methodology. The rest of this paper determines the conclusions and recommendations for the future research.

\section{MATERIAL AND METHODS}

\section{Ethical Aspect of Research}

Data were obtained from the OECD ilibrary database for the purpose of this study. The data used is provided as an open source of access for the community. ${ }^{11}$

\section{Data and Methods}

HE of Turkey was discussed in the period from 1975 to 2050 (74 years) in this research. Data on HE of Turkey for the years 1975-2017 were provided by the OECD under the title as Health expenditure and financing: Health expenditure indicators. ${ }^{11}$ The method of the present study used trendlines approach to foresee HE of Turkey. Trendline analysis can be expressed as a linear or nonlinear least squares regression equations to create a correlation with data points that have noticeably no associating. The trend line analysis is a built-in analysis tool in statistical software. ${ }^{23}$ Inferential decisions were examined for data from multiple trendlines in order to evaluate the data from the single data set regarding of HE. The future estimation of the equations revealed by the Trendlines approach was made for $\mathrm{HE}$ based on the $\mathrm{R}^{2}$ values. The $\mathrm{R}$-square is explained as a statistical measure of how close it is to the appropriate equation regression line by inferring with the data obtained. The percentage of the variation of the response variable obtained in a linear model is the most used one in the studies. ${ }^{24}$ The data used for HE of Turkey is ranged between $1.49 \%$ and $5.53 \%$ of GDP (as a share of GDP). 
Table 1 shows government and out-ofpocket payments expenditure on healthcare as a share of GDP of Turkey for the period from 1975 to 2017 over 42 years. The highest HE became by $5.53 \%$ in 2009 , while the lowest HE had in 1980 by $1.49 \%$ in Turkey. Critical, Turkey, as it is necessary to further improve its HE by avoiding wasted expenditure. While the expenditures before 1998 were below the average, the data after 1998 were above the average. In the last two decades, we may argue that HE is more than the expenditure made for the period from 1975 to 1998 over 23 years.

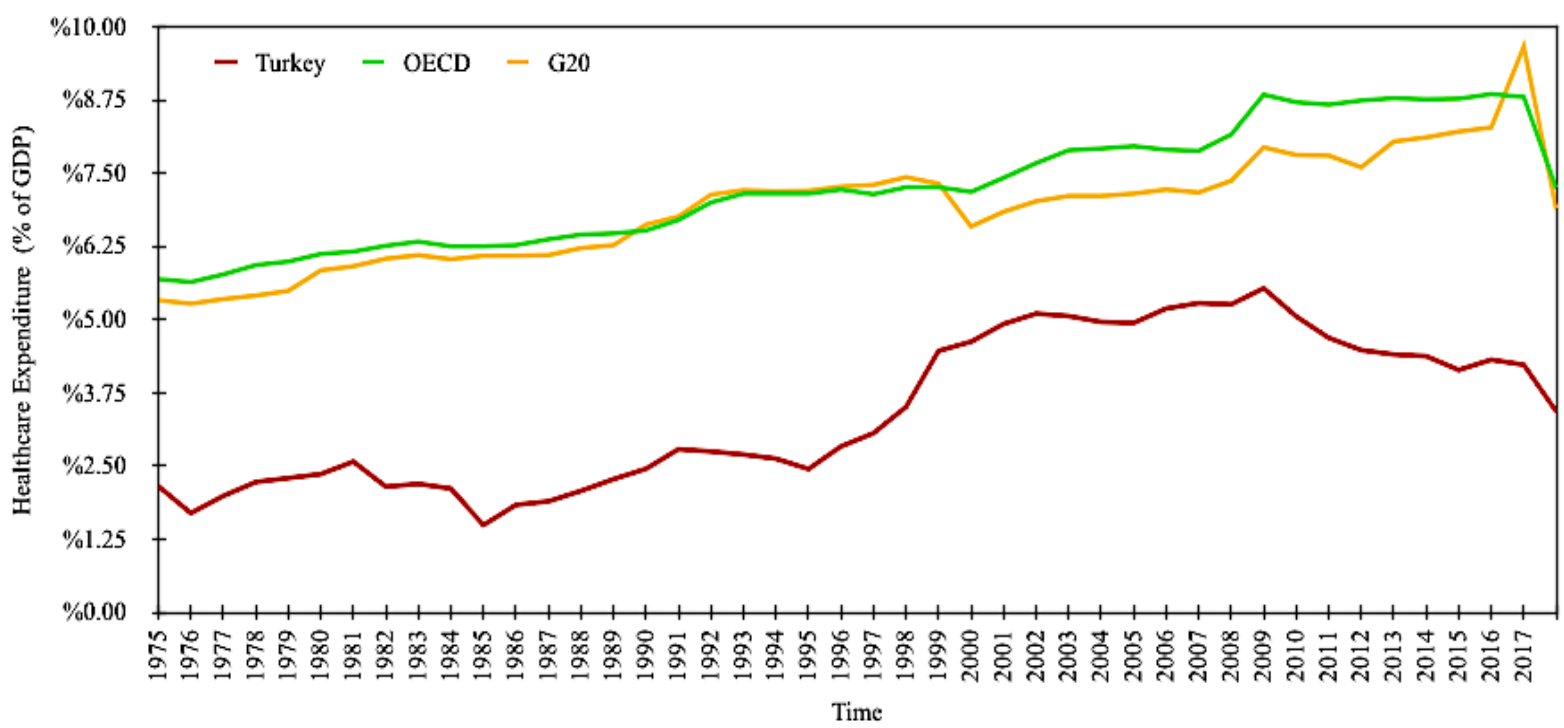

Figure 1: Healthcare Expenditures (\% of GDP) of OECD, G20, and Turkey for the period from 1975 to 2017

HE of Turkey is located beneath the rate of HE owned by both the OECD and G20 members in the year under consideration for this research. During this period, the average ratio of HE of Turkey was calculated as 3.43 $\%$, while the average ratio of $\mathrm{HE}$ belonging to the OECD and G20 countries was observed as $7.24 \%$, and $6.88 \%$, respectively. Although HE increased after 2000, there was are markable decrease in HE for all observed countries in 2017.Between 1975 and 2017, the HE rates of OECD members closely followed the $\mathrm{HE}$ rates of $\mathrm{G} 20$ countries.

The year of 1998 can be defined as a breakeven point for HE of Turkey. After this year, we can argue that the amount of HE is above the average. Between the year of 1975 and 2009 , total healthcare expenditure grew each year, except 1976, 1985, and 1995. After 2009, HE of Turkey have begun to decline dramatically (There is a loss of approximately $1.40 \%$ ). The fact that such a situation should not be expected to lead to a significant increase in the coming years in terms of HE.
Because the data of the past years directly affect the results to be obtained for the future.

According to the obtained linear equation, the reliability rate of the data was calculated as 0.7326 according to $\mathrm{R}^{2}$. The equation obtained was formulated as follows:

$$
y=0.009 * x+0.0148+p
$$

where, $y$ represents $\mathrm{HE}$ as the response variable, while $x$ symbolizes the next years for forecasting as an independent variable, $p$ denotes predictor of the response variable in all inequalities in this study. According to the equation, the response variable $y(\mathrm{HE})$ is only connected with the coming years $(x)$. Contrariwise, the coefficient of nondetermination describes the amount of inexplicable for, the variance between two factors, or between a set of variables (forecasters) in a response variable. The following formula was developed in the calculation of $p$ :

$$
p=\left(1-R^{2}\right) * c
$$




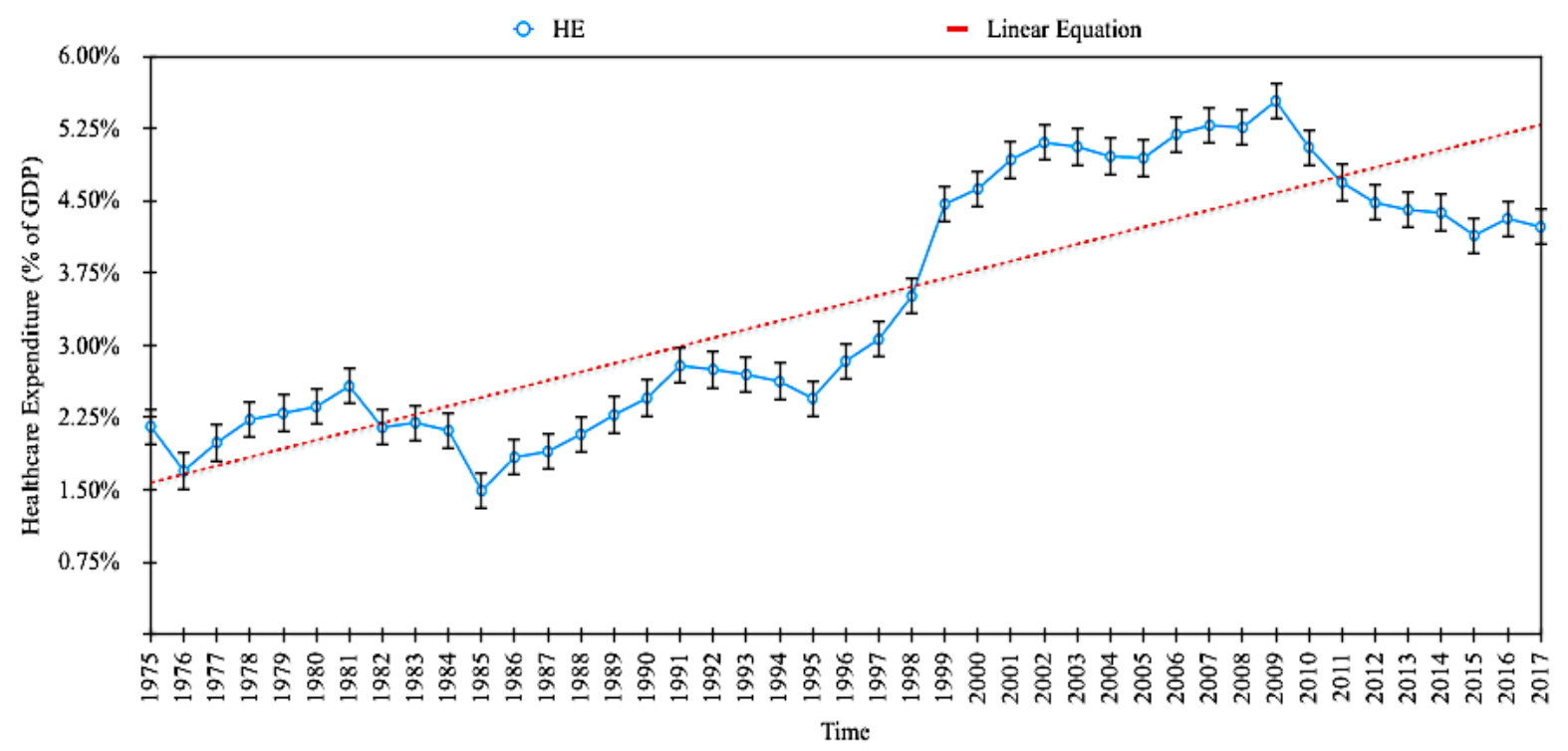

Figure 2. Trendline According to Linear Equation

A logarithmic curve according to the order in which the data is located exhibits a nonlinear approach. It is stated that the logarithmic line has a lower reliability ratio than the linear equation. The calculated $\mathrm{R}^{2}$ value for this equation is 0.5616 . The $\mathrm{R}^{2}$ value of the data is lower, as compared to the other parameters' results. The equation is expressed as follows:

$$
y=0.0111 * \ln (x)+0.003+p
$$

The logarithmic distribution of the powerorder line obtained as a result of the distribution of the data was developed. As compared to the $\mathrm{R}^{2}$ of other equations, a power equation with the second lowest $\mathrm{R}^{2}$ (0.5928) value was obtained. The mathematical formula of the HE was given as:

$$
y=0.012 * x^{0.3464}+p
$$

The data show an exponential tendency and is among the parabolic and linear inclinations of the equation to be obtained. The calculated value of $R^{2}(0.7565)$ from the data used was acceptable. The equation was stated as below:

$$
y=0.0174 * e^{0.0274 * x}+p
$$

The following equation was obtained from a second-order parabolic equation with the value of $\mathrm{R}^{2}$ that is 0.7366 :

$$
\begin{array}{rl}
y=5.925 E^{-6} & * x^{2}+0.0011 \\
& * x+0.0129 \\
& +p
\end{array}
$$

Clutter can be detected in the data above and below the curve for the higher $\mathrm{R}^{2}$ value that the $3^{\text {rd }}$ order equation will obtain. This is to minimize the distance of the data to the curve. Another reason is to ensure that the amount of data remaining above and below the curve is equal, as in other graphs. The following equation was obtained from a third order parabolic equation with a high $\mathrm{R}^{2}$ (0.9047):

$$
\begin{array}{rl}
y=-3.512 E^{-6} & * x^{3}+2 E^{-5} \\
& * x^{2}-0.003 * x \\
& +0.0289+p
\end{array}
$$

The $\mathrm{R}^{2}$ obtained in the fourth-order equation spectacles a $5.00 \%$ excess of the $\mathrm{R}^{2}$ acquired from the third-order equation. This ensures that the margin of error is less in the estimation data to be obtained in this calculation. The data on HE, $y$ had a nonlinear fourth-degree polynomial equation, to achieve a high value of $\mathrm{R}^{2}(0.9181)$. The equation for the HE was given below: 


$$
\begin{array}{rl}
y=-9.208 E^{-8} & * x^{4} \\
& +4.59 E^{-6} * x^{3} \\
& -5.096 E^{-6} * x^{2} \\
& -0.0007 * x \\
& +0.0232+p
\end{array}
$$

For the purpose of keeping the $\mathrm{R}^{2}$ value (0.9528) high, the formulation shows a polynomial distribution with a fifth-degree equation. The equation that shows the HE of Turkey was formulated as below:

$$
\begin{array}{rl}
y=1.379 E^{-8} & * x^{5} \\
& -1.609 E^{-6} * x^{4} \\
& +6.426 E^{-5} * x^{3} \\
& -0.001 * x^{2} \\
& -0.0059 * x \\
& +0.012+p
\end{array}
$$

The trend line developed is similar to $3^{\text {rd }}$, $4^{\text {th }}$, and $5^{\text {th }}$ order equations for the $6^{\text {th }}$ order formulation. The data is close to the trend line. It can be argued that the margin of error is minimized. The $\mathrm{R}^{2}$ value of the data $(0.9591)$ is higher, as compared to the results of the other parameters. The line that was drawn for the data seems to be a polynomial $6^{\text {th }}$ order arch. The equational explanation of this connection was given below:

$$
\begin{array}{rl}
y=5.486 E^{-10} & * x^{6} \\
& -5.863 E^{-8} * x^{5} \\
& +2.031 E^{-6} * x^{4} \\
& -2.231 E^{-5} * x^{3} \\
& -2.572 E^{-5} * x^{2} \\
& -0.0013 * x \\
& +0.018+p
\end{array}
$$

Detailed information of the results of the study was given the following section.

\section{RESULTS AND DISCUSSION}

Data of the future 32 years were calculated by analyzing the data of the past 42 years for the HE of Turkey. The method of the trend line that predicted HE of Turkey best were then adopted for this study and its amount of expenditure predictive was verified. HE of Turkey for 2018 envisages $4.2 \%$ according to OECD database. With the methods developed in this study, the same data were obtained by the linear, and exponential equations. We have observed that the mean HE values of the 8 equations deviated from the OECD value by 0.11 . We claimed that the study had a $90 \%$ reliability rate. Table 1 shows the values of HE covered 2018-2050. The maximum, minimum and averages values of $\mathrm{HE}$ was calculated for the equations individually and interactively. Table 1 shows the development of the mean, maximum and minimum values of HCE for different estimated equations. According to the data on the distribution of power and logarithmic can always see the average expenditure is higher than the other equations. The evolution of data in the equations of $3^{\text {rd }}, 4^{\text {th }}, 5^{\text {th }}$, and $6^{\text {th }}$ order estimators is quite similar until the early 2031s, but the distance between these mean values continues to increase continuously. In 2014, while the equation in the $3^{\text {rd }}$ order equation decreased slightly in the period of 2019-2027, it increased slowly in the rest of the equations. Whereas the data of the equations according to the years are increasing gradually according to the maximum and average criteria, it is observed that there is uncertainty in terms of the minimum criteria. 
Table 1. Values of HE for the Period from 2018 to 2050 Obtained Based on the Functions

\begin{tabular}{|c|c|c|c|c|c|c|c|c|c|c|c|c|}
\hline Year & Linear & $\log$ & Power & Expo & $2^{\text {nd }}$ Order & $3^{\text {rd }}$ Order & $4^{\text {th }}$ Order & $5^{\text {th }}$ Order & $6^{\text {th }}$ Order & Min & Ave & $\operatorname{Max}$ \\
\hline 2018 & $4.24 \%$ & $4.68 \%$ & $5.27 \%$ & $4.22 \%$ & $4.03 \%$ & $3.56 \%$ & $3.07 \%$ & $2.17 \%$ & $2.33 \%$ & $2.17 \%$ & $3.73 \%$ & $5.27 \%$ \\
\hline 2019 & $4.33 \%$ & $5.45 \%$ & $5.6 \%$ & $4.27 \%$ & $4.15 \%$ & $3.32 \%$ & $3.00 \%$ & $2.5 \%$ & $2.44 \%$ & $2.44 \%$ & $3.9 \%$ & $5.6 \%$ \\
\hline 2020 & $4.42 \%$ & $5.9 \%$ & $5.83 \%$ & $4.32 \%$ & $4.26 \%$ & $3.11 \%$ & $2.94 \%$ & $2.7 \%$ & $2.53 \%$ & $2.53 \%$ & $4.00 \%$ & $5.9 \%$ \\
\hline 2021 & $4.51 \%$ & $6.22 \%$ & $6.01 \%$ & $4.38 \%$ & $4.37 \%$ & $2.94 \%$ & $2.88 \%$ & $2.8 \%$ & $2.59 \%$ & $2.59 \%$ & $4.08 \%$ & $6.22 \%$ \\
\hline 2022 & $4.6 \%$ & $6.47 \%$ & $6.17 \%$ & $4.43 \%$ & $4.49 \%$ & $2.8 \%$ & $2.83 \%$ & $2.83 \%$ & $2.63 \%$ & $2.63 \%$ & $4.14 \%$ & $6.47 \%$ \\
\hline 2023 & $4.69 \%$ & $6.67 \%$ & $6.3 \%$ & $4.49 \%$ & $4.61 \%$ & $2.69 \%$ & $2.79 \%$ & $2.8 \%$ & $2.63 \%$ & $2.63 \%$ & $4.19 \%$ & $6.67 \%$ \\
\hline 2024 & $4.78 \%$ & $6.84 \%$ & $6.43 \%$ & $4.54 \%$ & $4.72 \%$ & $2.6 \%$ & $2.76 \%$ & $2.74 \%$ & $2.62 \%$ & $2.6 \%$ & $4.23 \%$ & $6.84 \%$ \\
\hline 2025 & $4.87 \%$ & $6.99 \%$ & $6.54 \%$ & $4.6 \%$ & $4.84 \%$ & $2.54 \%$ & $2.74 \%$ & $2.67 \%$ & $2.6 \%$ & $2.54 \%$ & $4.27 \%$ & $6.99 \%$ \\
\hline 2026 & $4.96 \%$ & $7.12 \%$ & $6.64 \%$ & $4.66 \%$ & $4.96 \%$ & $2.51 \%$ & $2.74 \%$ & $2.59 \%$ & $2.56 \%$ & $2.51 \%$ & $4.31 \%$ & $7.12 \%$ \\
\hline 2027 & $5.05 \%$ & $7.24 \%$ & $6.74 \%$ & $4.72 \%$ & $5.08 \%$ & $2.49 \%$ & $2.75 \%$ & $2.53 \%$ & $2.52 \%$ & $2.49 \%$ & $4.35 \%$ & $7.24 \%$ \\
\hline 2028 & $5.14 \%$ & $7.35 \%$ & $6.83 \%$ & $4.79 \%$ & $5.21 \%$ & $2.5 \%$ & $2.78 \%$ & $2.48 \%$ & $2.48 \%$ & $2.48 \%$ & $4.39 \%$ & $7.35 \%$ \\
\hline 2029 & $5.23 \%$ & $7.44 \%$ & $6.91 \%$ & $4.85 \%$ & $5.33 \%$ & $2.52 \%$ & $2.83 \%$ & $2.46 \%$ & $2.46 \%$ & $2.46 \%$ & $4.45 \%$ & $7.44 \%$ \\
\hline 2030 & $5.32 \%$ & $7.53 \%$ & $6.99 \%$ & $4.92 \%$ & $5.45 \%$ & $2.55 \%$ & $2.89 \%$ & $2.48 \%$ & $2.45 \%$ & $2.45 \%$ & $4.51 \%$ & $7.53 \%$ \\
\hline 2031 & $5.41 \%$ & $7.61 \%$ & $7.07 \%$ & $4.99 \%$ & $5.58 \%$ & $2.6 \%$ & $2.96 \%$ & $2.53 \%$ & $2.47 \%$ & $2.47 \%$ & $4.58 \%$ & $7.61 \%$ \\
\hline 2032 & $5.5 \%$ & $7.69 \%$ & $7.14 \%$ & $5.06 \%$ & $5.71 \%$ & $2.66 \%$ & $3.06 \%$ & $2.61 \%$ & $2.51 \%$ & $2.51 \%$ & $4.66 \%$ & $7.69 \%$ \\
\hline 2033 & $5.59 \%$ & $7.76 \%$ & $7.21 \%$ & $5.13 \%$ & $5.84 \%$ & $2.72 \%$ & $3.17 \%$ & $2.73 \%$ & $2.58 \%$ & $2.58 \%$ & $4.75 \%$ & $7.76 \%$ \\
\hline 2034 & $5.68 \%$ & $7.83 \%$ & $7.27 \%$ & $5.21 \%$ & $5.97 \%$ & $2.8 \%$ & $3.29 \%$ & $2.89 \%$ & $2.68 \%$ & $2.68 \%$ & $4.85 \%$ & $7.83 \%$ \\
\hline 2035 & $5.77 \%$ & $7.89 \%$ & $7.34 \%$ & $5.28 \%$ & $6.1 \%$ & $2.87 \%$ & $3.42 \%$ & $3.08 \%$ & $2.81 \%$ & $2.81 \%$ & $4.95 \%$ & $7.89 \%$ \\
\hline 2036 & $5.86 \%$ & $7.95 \%$ & $7.4 \%$ & $5.36 \%$ & $6.23 \%$ & $2.95 \%$ & $3.57 \%$ & $3.3 \%$ & $2.98 \%$ & $2.95 \%$ & $5.07 \%$ & $7.95 \%$ \\
\hline 2037 & $5.95 \%$ & $8.01 \%$ & $7.46 \%$ & $5.44 \%$ & $6.36 \%$ & $3.03 \%$ & $3.73 \%$ & $3.55 \%$ & $3.18 \%$ & $3.03 \%$ & $5.19 \%$ & $8.01 \%$ \\
\hline 2038 & $6.04 \%$ & $8.06 \%$ & $7.52 \%$ & $5.53 \%$ & $6.5 \%$ & $3.11 \%$ & $3.9 \%$ & $3.81 \%$ & $3.4 \%$ & $3.11 \%$ & $5.32 \%$ & $8.06 \%$ \\
\hline 2039 & $6.13 \%$ & $8.12 \%$ & $7.57 \%$ & $5.61 \%$ & $6.63 \%$ & $3.18 \%$ & $4.08 \%$ & $4.09 \%$ & $3.65 \%$ & $3.18 \%$ & $5.45 \%$ & $8.12 \%$ \\
\hline 2040 & $6.22 \%$ & $8.16 \%$ & $7.63 \%$ & $5.7 \%$ & $6.77 \%$ & $3.25 \%$ & $4.27 \%$ & $4.38 \%$ & $3.91 \%$ & $3.25 \%$ & $5.59 \%$ & $8.16 \%$ \\
\hline 2041 & $6.31 \%$ & $8.21 \%$ & $7.68 \%$ & $5.79 \%$ & $6.91 \%$ & $3.31 \%$ & $4.46 \%$ & $4.66 \%$ & $4.19 \%$ & $3.31 \%$ & $5.72 \%$ & $8.21 \%$ \\
\hline 2042 & $6.4 \%$ & $8.26 \%$ & $7.73 \%$ & $5.89 \%$ & $7.04 \%$ & $3.35 \%$ & $4.65 \%$ & $4.94 \%$ & $4.47 \%$ & $3.35 \%$ & $5.86 \%$ & $8.26 \%$ \\
\hline 2043 & $6.49 \%$ & $8.3 \%$ & $7.78 \%$ & $5.98 \%$ & $7.18 \%$ & $3.39 \%$ & $4.83 \%$ & $5.21 \%$ & $4.74 \%$ & $3.39 \%$ & $5.99 \%$ & $8.3 \%$ \\
\hline 2044 & $6.58 \%$ & $8.34 \%$ & $7.83 \%$ & $6.08 \%$ & $7.33 \%$ & $3.41 \%$ & $5.02 \%$ & $5.46 \%$ & $4.99 \%$ & $3.41 \%$ & $6.12 \%$ & $8.34 \%$ \\
\hline 2045 & $6.67 \%$ & $8.38 \%$ & $7.88 \%$ & $6.18 \%$ & $7.47 \%$ & $3.41 \%$ & $5.2 \%$ & $5.69 \%$ & $5.23 \%$ & $3.41 \%$ & $6.23 \%$ & $8.38 \%$ \\
\hline 2046 & $6.76 \%$ & $8.42 \%$ & $7.92 \%$ & $6.29 \%$ & $7.61 \%$ & $3.4 \%$ & $5.36 \%$ & $5.89 \%$ & $5.43 \%$ & $3.4 \%$ & $6.34 \%$ & $8.42 \%$ \\
\hline 2047 & $6.85 \%$ & $8.46 \%$ & $7.97 \%$ & $6.39 \%$ & $7.76 \%$ & $3.36 \%$ & $5.51 \%$ & $6.05 \%$ & $5.59 \%$ & $3.36 \%$ & $6.44 \%$ & $8.46 \%$ \\
\hline 2048 & $6.94 \%$ & $8.5 \%$ & $8.01 \%$ & $6.5 \%$ & $7.9 \%$ & $3.3 \%$ & $5.65 \%$ & $6.18 \%$ & $5.71 \%$ & $3.3 \%$ & $6.52 \%$ & $8.5 \%$ \\
\hline 2049 & $7.03 \%$ & $8.53 \%$ & $8.06 \%$ & $6.62 \%$ & $8.05 \%$ & $3.21 \%$ & $5.76 \%$ & $6.27 \%$ & $5.77 \%$ & $3.21 \%$ & $6.59 \%$ & $8.53 \%$ \\
\hline 2050 & $7.12 \%$ & $8.57 \%$ & $8.1 \%$ & $6.73 \%$ & $8.2 \%$ & $3.1 \%$ & $5.85 \%$ & $6.33 \%$ & $5.78 \%$ & $3.1 \%$ & $6.64 \%$ & $8.57 \%$ \\
\hline Min & $4.24 \%$ & $4.68 \%$ & $5.27 \%$ & $4.22 \%$ & $4.03 \%$ & $2.49 \%$ & $2.74 \%$ & $2.17 \%$ & $2.33 \%$ & $2.17 \%$ & $3.58 \%$ & $5.27 \%$ \\
\hline Ave & $5.68 \%$ & $7.54 \%$ & $7.12 \%$ & $5.3 \%$ & $6.02 \%$ & $2.99 \%$ & $3.78 \%$ & $3.74 \%$ & $3.48 \%$ & $2.99 \%$ & $5.07 \%$ & $7.54 \%$ \\
\hline Max & $7.12 \%$ & $8.57 \%$ & $8.1 \%$ & $6.73 \%$ & $8.2 \%$ & $3.41 \%$ & $5.85 \%$ & $6.33 \%$ & $5.78 \%$ & $3.41 \%$ & $6.68 \%$ & $8.57 \%$ \\
\hline
\end{tabular}

With the trend line method, nine types of equations were obtained in this study. The occurrence of differences from the results obtained from the equations is assumed to be proportional to the calculated $\mathrm{R}^{2}$ value. For the 42 years, the equation of the equation with the highest data gap is the second-order equation. This rate is calculated as approximately $4.17 \%$. This is the equation in the $5^{\text {th }}$ degree equation with the calculation of 
$4.16 \%$. The distance between the data found in the logarithmic equation, which is an example of polynomial distribution, is $3.88 \%$. This rate is $3.45 \%$ of the rate is in the $6^{\text {th }}$ equation. The data range in linear, power, exponential, and $4^{\text {th }}$ order equations are approximately between $2.78 \%$ and $2.88 \%$. The equation with the lowest data range is the equation of the $3^{\text {rd }}$ degree order. The closeness of data between the data causes the distance between the 32-year data to be the lowest. While the ratio between the maximum and minimum value of $\mathrm{HE}$ is $0.92 \%$ within 32 years, it is perceived as $0.47 \%$ between 2018 and 2050 .
Figure 3 shows the changes in the values of the equations obtained over the years. Though the 5 of 9 equations obtained performance a negative tendency for a certain period of time, the direction of the remaining equations behaves as positive. The most important point that stands out in this graph is that the thirdorder equation is the negative direction of drawing and is below the average HE, unlike the other equations. The gap between the calculated HE values stands at $6.40 \%$. This ratio represents the maximum and minimum values of the endpoints. This break was calculated as $4.04 \%$ for the period from 1975 to 2017. It has been observed that $36.84 \%$ improvement was achieved in the first 42 years and in the last 32 years.

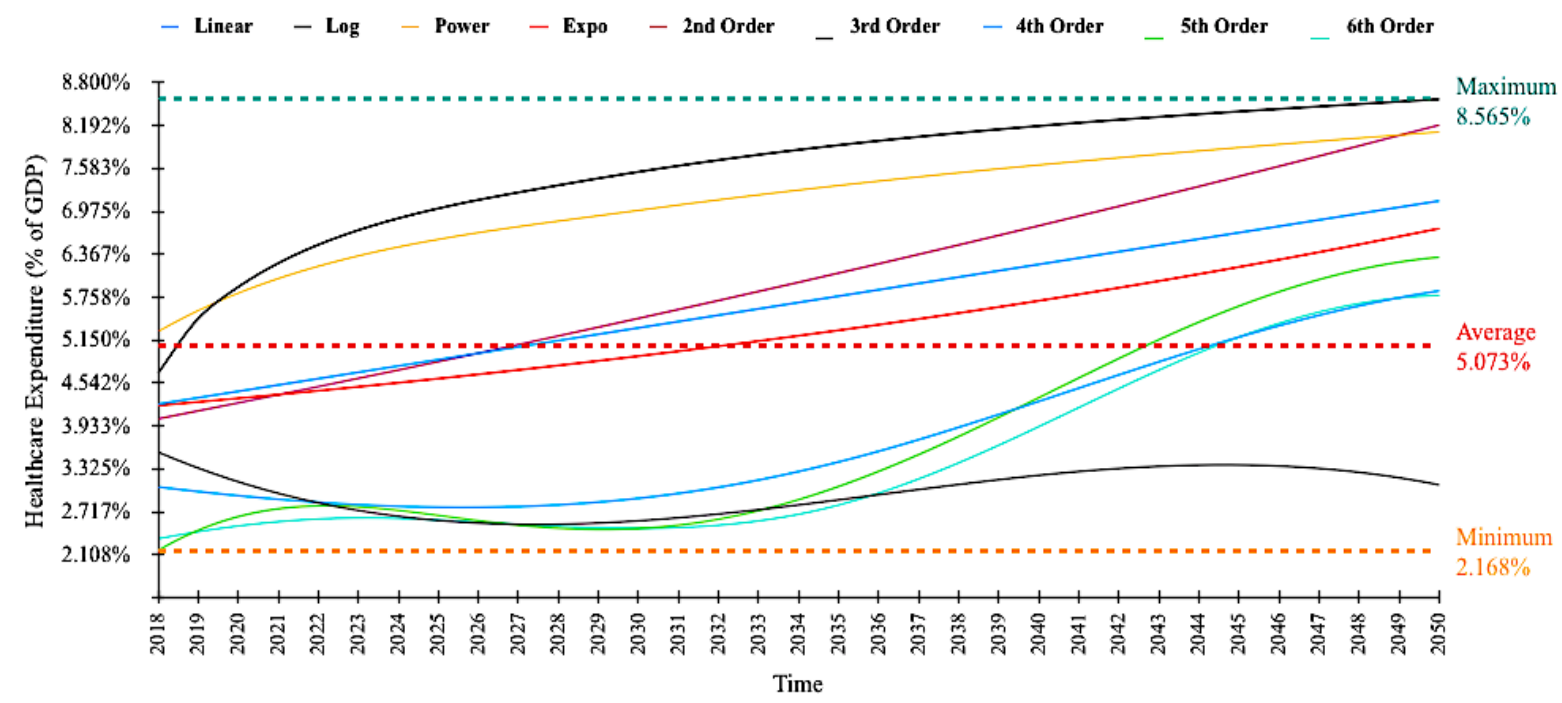

Figure 3. HE (\% of GDP) for the period from 2018 to 2050

For the years to come, the maximum ratio of $\mathrm{HE}$ to $8.57 \%$ was obtained by the exponential trend for the year 2050. In the opposite direction, the minimum HE ratio was obtained as $2.17 \%$ by the fifth-degree equation for 2018. $7.45 \%$ covers the years after 2030 due to exponential distribution for the average the values of HE. While the average value obtained by the equation in the sixth-order equation which has the highest reliability rate was computed as $3.48 \%$, the difference between the maximum and the minimum was calculated as $3.45 \%$. As a result, for the period of 2018 to 2050, an average of HE rates of Turkey was $5.07 \%$, while the maximum value was estimated by $6.68 \%$. The minimum value of $\mathrm{HE}$ was assessed at $3.58 \%$ of GDP.

The outcomes of the identified analysis are more credible than the results of previous reports and studies in this study. Basing the results obtained in the studies using different approaches to interpretations and the results obtained in this study based on numerical results increases the accuracy of the decisions. 


\section{CONCLUSION AND RECOMMENDATIONS}

In summary, for the first time, derivation equations were formulated for HE of Turkey by trendline analysis in the present study. According to the trendline analysis, calculation of HE of Turkey was recorded for the period from 2018 to 2050 . While 5 of the 9 equations obtained performances with the negative tendency for a certain period of time, the direction of the remaining equations behaves as positively. The results were found to be below the average as compared to the HE of OECD and G20 members. The average of the OECD members' $\mathrm{HE}$ is approximately $8.80 \%$, while the average value of G20 countries is almost $9.66 \%$ for $2017 .{ }^{11}$ In the same year, HE of Turkey was calculated as the ratio of $4.23 \%$ that addresses lags behind the average of two organizations. The ultimate goal of this study was to measure the amount of medical expenses for Turkey's future. The ratio of HE will show how much support is also given to the technical and medical infrastructure required in the healthcare field in Turkey. In the studies on HE of Turkey, the relationship between $\mathrm{HE}$ and economic development is strongly explained. This research presents Turkey' spends in the field of health which gives the opportunity to predict the growth of the future economic size of Turkey.

\section{REFERENCES}

1. Novak S, Djordjevic N. (2019). Information system for evaluation of healthcare expenditure and health monitoring. Phys A Stat Mech its Appl, 520, 72-80

2. Özcan T, Tüysüz F. (2018). Healthcare expenditure prediction in Turkey by using genetic algorithm based grey forecasting models. In: International Series in Operations Research and Management Science.

3. Eriksen S, Wiese R. (2019). Policy induced increases in private healthcare financing provide short-term relief of total healthcare expenditure growth: Evidence from OECD countries. Eur J Polit Econ.

4. Goel V, Rosella LC, Fu L, Alberga A. (2018). The Relationship Between Life Satisfaction and Healthcare Utilization: A Longitudinal Study. Am J Prev Med, 55 (2), 142-150.

5. Quercioli C, Nisticò F, Troiano G, et al. (2018). Developing a new predictor of health expenditure: preliminary results from a primary healthcare setting. Public Health, 163, 121-127.

6. Atalan A, Dönmez CÇ. (2018). Yüksek-Eğitimli Uzman Hemșire İstihdamı ile Acil Servis Kalitesinin Yükseltilmesi için Simülasyon Uygulaması: Türkiye Sağlık Sistemi. Marmara Fen Bilim Derg, 30 (4), 318-338.

7. Xu K, Saksena P, Holly A. (2011). The Determinants of Health Expenditure : A Country-Level Panel Data Analysis. Work Pap Results Dev Inst.

8. Atalan A. (2019). The Impacts of Healthcare Resources on Services of Emergency Department: Discrete Event Simulation with Box-Behnken Design. PONTE Int Sci Res J, 75 (6), 12-23.

9. Clemente J, Lázaro-Alquézar A, Montañés A. (2019). US state health expenditure convergence: A revisited analysis. Econ Model.

10. Liang L-L, Tussing AD. (2019). The cyclicality of government health expenditure and its effects on population health. Health Policy (New York), 123 (1), 96-103.

11. OECD. (2018). Health Expenditure and Financing: Health Expenditure Indicators (Edition 2018).

12. van Beusekom I, Bakhshi-Raiez F, de Keizer NF, van der Schaaf M, Busschers WB, Dongelmans DA. (2018). Healthcare costs of ICU survivors are higher before and after ICU admission compared to a population based control group: A descriptive study combining healthcare insurance data and data from a Dutch national quality registry. J Crit Care, 44, 345-351.
13. Toth F. (2016). Classification of healthcare systems: Can we go further? Health Policy (New York), 120 (5), 535-543.

14. Manning WG. (2014). Modeling Cost and Expenditure for Healthcare. In: Culyer AJ, ed. Encyclopedia of Health Economics. San Diego: Elsevier, 299-305.

15. Wörz S, Bernhardt H. A new forecasting method for univariate time series. J Comput Appl Math. November 2018.

16. Kotu V, Deshpande B. (2019). Chapter 12 - Time Series Forecasting. In: Kotu V, Deshpande BBT-DS (Second E, eds. Morgan Kaufmann, 395-445.

17. Folgado D, Barandas M, Matias R, Martins R, Carvalho M, Gamboa H. (2018). Time Alignment Measurement for Time Series. Pattern Recognit, 81, 268-279.

18. Mao Q, Zhang K, Yan W, Cheng C. (2018). Forecasting the incidence of tuberculosis in China using the seasonal autoregressive integrated moving average (SARIMA) model. J Infect Public Health, 11 (5), 707-712.

19. Atalan A, Donmez C. (2019). Employment of Emergency Advanced Nurses of Turkey: A Discrete-Event Simulation Application. Processes, 7 (1), 48.

20. Granger CW. (1980). Chapter 2 - Trend-Line Fitting and Forecasting. In: Granger CWJ, ed. Forecasting in Business and Economics. Academic Press, 19-40

21. Qin W, Zhang Y, Chen J, et al. (2019). Variation, sources and historical trend of black carbon in Beijing, China based on ground observation and MERRA-2 reanalysis data. Environ Pollut, 245, 853-863.

22. Lessmann S, Voß S. (2017). Car resale price forecasting: The impact of regression method, private information, and heterogeneity on forecast accuracy. Int J Forecast, 33 (4), 864 877.

23. Atalan A. (2018). Türkiye Sağlık Ekonomisi için İstatistiksel Çok Amaçlı Optimizasyon Modelinin Uygulanması. İşletme Ekon ve Yönetim Araştırmaları Derg, 1 (1), 34-51.

24. Ricci L. (2010). Adjusted R-squared type measure for exponential dispersion models. Stat Probab Lett, 80, 1365-1368. 